\title{
Can Smartphones Pave the Path towards EFL Competence for Saudi College Students?
}

\author{
Mahgoub Dafalla Ahmed ${ }^{* 1, * 2}$ \\ ${ }^{* 1}$ Department of English \& Translation, Faculty of Science \& Arts, King Abdulaziz \\ University, Jeddah, Saudi Arabia \\ ${ }^{* 2}$ Department of English \& Translation, Faculty of Science \& Arts, Khulais Branch, \\ University of Jeddah, Jeddah, Saudi Arabia
}

Tel: 00966-534-053-521. E-mail: mahgoub7700@hotmail.com

Received: October 23, 2015 Accepted: November 24, 2015 Published: November 25, 2015

doi:10.5296/elr.v1i2.8467

URL: http://dx.doi.org/10.5296/elr.v1i2.8467

\begin{abstract}
The study reported here focuses on how modern technology, specifically smartphones can pave the path towards English as a foreign language (EFL) competence. It emphasizes on how smartphones can enhance EFL learning where the focus is mainly on the acquired linguistic knowledge and language skills. It sheds light on language competence in more general terms and learners' vocabulary acquisition, listening, speaking, reading and writing, in particular. The sample for the study was drawn from Saudi college students at the faculty of Science and Arts, Khulais Branch at King Abdulaziz University, Saudi Arabia. After conducting an Entry Level English language Test, 50 students from the preparatory year were selected. Then, they were split into two homogenous groups. The first group (control group) was instructed in the conventional way, while the second group (experimental group) was offered instruction and encouraged to learn through smartphones. Results showed that the participants who received treatment (experimental group) significantly outperformed than the other group. It revealed that employing smartphones yielded a positive result. Additionally, results showed that students in the experimental group who used smartphones were more enthusiastic and driven than their counterparts in the control group who were still stuck in paper-text materials.
\end{abstract}

Keywords: EFL learners, L2 learners, language learning, mobile aided language learning (MALL), m-learning, mobile devices, mobile phones, mobile technology, smartphones 


\section{Introduction}

Despite the fact that the field of integrating smartphones in education is an emerging phase, this study attempts to embrace their constructive uses in learning EFL and explore to what extent they reinforce autonomy in language learning. It focuses on enhancing EFL competence through using smartphones. In general, the study considers the features of smartphones that encourage interaction with a foreign culture and explores the range of tasks for which learners use these devices. Incorporating such technology in classrooms, students are expected to be competent and be able enough to pursue learning independently.

The wide spread of broadband wireless networks and the specifications and capabilities of the new generation of smartphones make it evident that they have immense possibilities in EFL learning. In addition, the inexpensive internet services offered by mobile operators increase the use of smartphones by students in learning. This widespread use of mobile and wireless devices motivates learners to engage in several activities. Besides, various factors encourage education experts in Saudi Arabia to utilize mobile technology in education through "m-learning". One of these factors is the limited exposure of EFL learners to English. Students in Saudi Arabia use English only in classes in few hours per week, and EFL learners with mobile learning (MALL) presumably will be exposed largely to the target culture as independent learners (Thornton \& Houser, 2005; Chinnery, 2006). In this vein, Lu, 2008 notes, MALL increases learners' exposure to the target language for its availability and convenience. Another factor is that Saudi Arabia is an oil-rich country, and consequently the standard of living is very high, which results in the easy availability of smartphones among Saudi students. One more factor has resulted from the new educational trend that favors employing technology in academics. Nowadays, technology has replaced traditional ways of language learning such as learning in formal classroom setting. Nearly all educational institutions in Saudi Arabia are competing in adopting and using modern technology in their learning systems. A further notable factor is that students prefer to learn using technology rather than through traditional learning. Today's students are totally different and have different learning needs and styles. Teachers have to put into their considerations that they are dealing with students being identified as 'Generation C', who are growing up in the digital world, full of computers and mobile devices (Duncan-Howell \& Lee, 2007). Technology is an integral part of their lives because they were born into it, so if it is not employed in their learning, they will feel isolated and disconnected. All the above factors and many other contributing reasons encourage education experts to extend using mobile learning to substitute the traditional learning environments. They ask teachers to exploit this fad as a tool for learning in general and language learning in particular.

\section{Literature Review}

\subsection{Defining M-Learning}

Although there have been several attempts at defining m-learning, this concept has not been clearly defined yet. All over the world, universities and research centres are holding conferences and seminars in search of a precise definition for it. Sometimes m-learning is regarded as a part or an extension of e-learning. However, in scholarly literature, m-learning 


\section{Macrothink}

refers to the use of portable devices in education. For Lehner and Nosekabel (2002), m-learning means any facility which helps in acquiring of knowledge anytime and anywhere. Attewell, Savill-Smith, \& Douch (2009, p. 1) state, m-learning means using portable devices to facilitate and enhance teaching and learning. Park et al (2012, p. 592) define m-learning as providing education only through handheld or palmtop devices. According to Chinnery (2006, p. 9), mobile learning can be described as taking place in environments that could be used both within and outside the classroom (Koole, 2009). In educational settings, m-learning means providing education using modern technologies to support students' language learning such as smartphones, tablets, MP3/MP4 players, personal digital assistants (PDAs) and palmtop computers (Traxler, 2009b, p. 2), and Zhao (2005, p. 447).

\subsection{Using Mobile Technology in Language Learning}

Studies have shown that MALL encourages study without instructor intervention and increases success in language learning. Many researchers such as Fowler et al., 1996; Resta \& Laferrieri, 2007; Hoic-Bozic et al. (2009) assert that technology is able to generate collaborative learning and help students become independent learners. Yunus, et al. (2010) note that the improvements in language learning resulted from integrating technology such as using mobile phones. Kondo et al. (2012) investigate whether mobile devices can be used to foster a self-regulated style of learning. They reach the conclusion that MALL encourages students to study without instructor intervention and increases their achievements. O'Conner (2005) discusses how to change mobile phones into tools for learning instead of toys in order to be used constructively. Morris (2011) explores incorporating technology to develop learning, especially the use of mobile phones in EFL classroom. Reinders (2010) introduces some of the practical uses of technology in English classes like using features of a camera to compile everyday language, VMR to record conversations or text messaging of mobile phones. Similarly, Kolb (2008) in "Toys and Tools" provides information about the educational use of mobile phones and discusses some practical uses of mobile phones in teaching and learning. Al-Shehri (2011) argues that mobile technology offers learners authentic opportunities to engage in learning processes outside classrooms. Begum's (2011) study reveals the advantages of mobile phones as an instructional tool. Miangah and Nezarat (2012) point out that mobile learning contributes to personalize learning processes making it spontaneous, informal and continuous. In contrast, Pemberton and Fallahkhair (2005) hold contradictory views regarding mobile learning, preferring interactive television to MALL.

\subsection{Why Mobile Phones and Specifically Smartphones?}

Since its emergence, for many reasons, students all over the world prefer using smartphones to other mobile devices. Smartphones are small, ubiquitous, and functional, which makes them attractive and easy for students to use and it facilitates sociocultural opportunities for learning (Pachler, Cook, \& Bradley, 2009). The broadband connection via Wi-Fi and Wi-MAX is a great advantage. It enables users to gain great flexibility due to the data processing capability of these devices via $3 \mathrm{G}$ or $4 \mathrm{G}$ networks. Besides, smartphones nowadays are produced with larger screen size, and very high pixel resolutions. The processing power (CPU) of smartphones is also continuing to evolve and the memory cards 
can store very large data. In addition, more and more functions have been integrated within these devices, which enable users to access unlimited applications and perform many functions.

\subsection{Language Skills Where Smartphones Assist}

Definitely, this study could not cover the whole options that are available for using smartphones in language skills. Briefly, it introduces some functions and applications smartphones provide. It also explores how these functions and applications can be beneficial to language learners. In general, the emphasis relates to the use of smartphones in enhancing different aspects in foreign language learning and their pedagogical benefits. Attention is primarily on acquiring linguistic knowledge and skills. The reflection is on the improvement in learners' vocabulary, grammar, reading, writing, speaking and listening skills. The challenge for mobile learning, then, is to build a deeper and more pedagogically solid understanding of the ways in which learners use a variety of mobile devices and the effectiveness of these devices in offering various learning opportunities.

The type of activities varies with the difference on the level of language proficiency of the learners. Common ways of learning vocabulary activities include sending e-mail or SMS to students. The SMS lessons offer a novel learning experience as well as a relaxing condition. New vocabulary can be introduced in multiple contexts to infer the meaning. Some vocabulary can be accompanied by pictorial annotation for better understanding. Using their smartphones, students complete the tasks and send them back to their teachers for feedback. Another appropriate form of vocabulary instruction in EFL is learning through wordlists. L2 words are listed together with their L1 translations (Read, 2000, p.40).

Sharpless (2009) notes the limitations of published research on the impact of MALL on learners' opportunities to speak and listen to the language, and research has shown that students and instructors do not make full use of the "anytime, anyplace" capabilities (Geddes, 2004 , p. 1). Smartphones could access various multimedia functions and encourage collaborative speaking, listening and pronunciation. In pronunciation, for example, students could learn major concepts like individual sounds, stress, phrasing, rhythm, and intonation. Through smartphones, also students have chances to record their oral assignments and upload these recordings to their teachers to provide feedback. Hoven and Palalas (2011) examine mobility with an iPad Touch in a university-level blended course in English for accounting. Their study reports high levels of student satisfaction with this mobile device and reports that the mobile listening option was superior to text-based resources. Through many websites, a great amount of authentic material, which is readily applicable, up-to-date, and free, can be used for listening skills. For example, teachers and students can access online authentic listening material from radio or TV programmes for listening, teaching and practice (Mosquera, 2001). Listening to podcasts, the delivery of audio and video files through the web creates more opportunities for honing students' language skills. It has several advantages to language learners and encourages them to participate actively in learning. Constantine P. (2007) notes that through podcasts students can access authentic texts and listen to a variety of voices. 
Instructing EFL reading can be done by smartphones, which help to solve many problems there. Smartphones offer students chances to practise reading independently and get feedback. The availability of web-based activities and electronic dictionaries helps students to be exposed to authentic texts and to practise reading extensively (Chun, 2006, p. 69). Many studies deal with EFL reading skills through mobile technology. One of them includes those of Lan et al. (2007, 2009), which try to solve the problems of traditional EFL reading activities with mobile technology. Attewell \& Webster, 2004; Chinnery, 2006) clarify the advantages of MALL for young EFL learners. Al-Seghayer (2007) finds the importance of hypertext for less proficient readers.

Teachers can encourage their students to write longer texts (not just SMSs and IM chats) on their smartphones. Teaching writing in the old-fashioned mechanical way is just boring to students. These days, students are accustomed to new forms of texts like images, videos, hyperlinks and infographics because they are the main components of their digital world. Technology such as using smartphones can drive away boredom from classroom and spur up creativity and engagement. Teachers can use many digital tools to encourage their students to improve their writing skills and make them love writing e.g. 'Google Docs', 'Zoho Docs', 'wikis', and 'Titan Pad' (Cress \& Kimmerle, 2008). Blogs also do well in improving writing (Alexander, 2006; Seitzinger, 2006; Sarica \& Cavus, 2009). Teachers should also encourage students to use applications like a user-friendly dictionary/thesaurus app, note taking apps, brainstorming and outlining apps, applications for developing writing skills and file storage and organization.

Baleghizadeh and Oladrostam (2010) note, mobile phone devices have their impact on the learning of grammar. They find that EFL students in the group who has access to mobile phones score better than the group without access to mobile phones. Learners acquire competency in grammar when they interact within meaning-rich contexts provided by technologies and concur with the cognitive approach such as text-reconstruction, concordance, telecommunications, multimedia simulation software, ..etc. Examples of using smartphones in practising the grammar, teachers can ask their students to take photos of written English around e.g. signs, notices, etc. to notice the misuse of grammar. Also, teachers can check the grammar by giving students gapped sentences.

\section{Research Questions}

Based on the main purpose of the research and the scope of the study, the researcher would try to find out logical answers to the following proposed questions:

1) Is there statistically significant difference for Saudi college students between learning EFL listening, grammar, vocabulary, reading and writing using smartphones or paper materials?

2) What are the frequent areas wherein smartphones help in learning EFL?

\section{Research Methodology}

A mixed methods design was used in this study with its both quantitative data (from tests) 
and qualitative data (from a questionnaire).

\subsection{Participants}

The data of this study was mainly collected from fifty male students randomly selected from the Faculty of Science and Arts, Khulais Branch at King Abdulaziz University, Jeddah, Saudi Arabia. They were Saudi EFL learners at college level studying at the preparatory year. At the time of testing, they had been through six years of learning English. Their ages ranged from 18 to 20 .

\subsection{Materials}

\subsubsection{The Tests}

Testing their level of language proficiency, students took an Entry Level English language Test two weeks before the study. This test is held every year for the students at the preparatory year as a pre-test. However, to obtain information for his study, the researcher mainly depended on the students' scores on the post-test (see Appendix 1). The post-test, introduced at the end of the treatment period, was formed of 20 multiple-choice items in addition to a question for practising writing skill. The questions tested the students' skills in listening, reading, vocabulary, grammar and writing. The two groups received the post-test in its conventional way. The listening section, which was adapted from the book Interaction 1, listening and speaking, contained five questions. The listening comprehension questions were based on the text designed. The vocabulary questions, which were mostly found online, contained five questions, too. Depending on students' levels of language proficiency, new words were introduced in multiple contexts to infer their meanings. Regarding the reading and the writing sections, the reading passage was adapted from "Havefunteaching.comskill-reading comprehension", and the writing from "English for everyone.org". The researcher assessed the students' writing according to their abilities in specific skills. They were evaluated according to the standardized writing assessment ERB (Educational Records Bureau) on six criteria. Each criterion was evaluated individually. Both reading and writing materials were found online. Regarding the grammar section, the questions consisted of grammatical rules, followed by questions and alternative where students selected the correct answers. They were appropriate to the levels of students in Saudi Arabia.

\subsubsection{The Questionnaire}

Finishing the post-test, students at the experimental group had to answer the questionnaire designed for gathering the qualitative data. Information obtained mainly concerned about whether using smartphones helped in learning EFL. The questionnaire consisted of four parts. In part one, participants wrote their personal information: grade and level. The second part was designed in the three - point scale ("Always", "Sometimes", and "Never".) Participants chose answers according to their opinions. The survey consisted of 30 carefully prepared statements evaluating descriptive aspects of using smartphones. Students provided answers on how smartphones enhanced their EFL learning vocabulary acquisition, listening, speaking, reading and writing. In the fourth part, they demonstrated other benefits of smartphones for other college work. 


\subsubsection{Reliability and Validity}

For equivalency purpose between the control and the experimental groups, the tests used covered all English language skills. They were validated through examining by a number of faculty members. Then they were piloted on separate groups of students.

Once the potential items were generated, reliability analysis to investigate the internal consistency of the survey's statements was carried out. To verify and strengthen validity and reliability, a pilot run was found necessary for rewording ambiguous or poorly worded items and to eliminate unsuitable, or to add other appropriate items. These procedures were also done through many faculty members and classroom practitioners. Only changes like substituting some vocabulary items were suggested. As there were no substantial suggestions for change, no modifications were made in the questionnaire.

\subsubsection{Procedures}

The students were divided into two groups (control and experimental). They were two homogenous groups (each one consisted of 25 participants). The control group received the conventional way of instructions. All students in the experimental group were encouraged to use their own smartphones (blackberry, Samsung galaxy or iPhone). Throughout the whole semester (16 sessions) in a spaced and scheduled pattern of delivery (two times a week), this group received the learning content through their smartphones. During this period, students in the experimental group studied and got feedback through their smartphones. They did all the tasks required inside and outside classrooms using their smartphones. The skills were taught to the groups as follows:

Listening and speaking: Students made audio and video recordings for themselves, classmates and others, downloaded and uploaded audio and video files and listened to them during their spare time. English listening exercises on the smartphones were sent to them. Then, students sent their answers to the instructors' smartphones to be marked.

Vocabulary: Students used their smartphones as notebooks to record new vocabulary on them. They also used online dictionaries and thesauruses. Covering the lessons introduced in the classroom, students received questions in messages and replied via similar messages.

Reading and Writing: Students downloaded and read their English course book (The Interaction 1, reading and writing), other relevant English e-books, magazines and newspapers. They were provided with different reading texts to evaluate their reading comprehension skill. These reading passages were installed in learners' smartphones. In writing lessons, students used their smartphones to take notes, chat, tweet and write thoughts, e-mails and short paragraphs.

Grammar: In the grammar lessons, questions were sent to learners' smartphones, in which there were grammatical rules, followed by multiple-choice questions where students selected the correct answers from the given alternatives. Students sent messages for grammatical questions to their teachers and peers.

At the end of the treatment period, the post-test was conducted to both groups to assess the 
efficacy of the treatment with the experimental group. The test was distributed through paper to both groups. All subjects completed the test in one session. Then, the questionnaire was distributed directly at the end of the test to the experimental group.

\section{Analysis, Results and Discussions}

\subsection{Results Related to Question 1}

Is there statistically significant difference for Saudi college students between learning EFL listening, vocabulary, grammar, reading and writing using smartphones or paper materials?

Using Paired Sample test, the mean scores of the selected students in the control group (CG) and the experimental group (EG) on the pre-test are calculated. The researcher assumes if the results show that there is close means between the two groups, then this result means the two groups are homogeneous before starting the treatment.

Table 1. The paired sample statistics of the two groups

\begin{tabular}{llllll}
\hline Group & Test & $\mathrm{N}$ & Mean & Std. Deviation & Std. Error Mean \\
\hline Control Group & Pre-test & 25 & 12.52 & 2.931 & 0.586 \\
Experimental Group & Pre-test & 25 & 11.16 & 2.853 & 0.571 \\
\hline
\end{tabular}

The Mean Scores in the Pre-test of the Control and the Experimental Groups

As expected, the results of the paired sample show close means on the pre-test for the two groups $(12.52,11.16)$. The researcher considers this result means that the levels of two groups are similar and any significant difference in the means on the post-test will be attributed to the treatment i.e. using smartphones in language learning. Table 2 and Table 3 compare the mean scores of the pre-test and the post-test for the two groups.

Table 2. The Paired Sample Statistics of the two tests.

\begin{tabular}{llllll}
\hline Group & Test & N & Mean & Std. Deviation & Std. Error Mean \\
\hline Control Group & Pre-test & 25 & 12.52 & 2.931 & 0.586 \\
& Post-test & 25 & 13.48 & 2.756 & 0.551 \\
Experimental Group & Pre-test & 25 & 11.16 & 2.853 & 0.571 \\
& Post-test & 25 & 15.72 & 1.926 & 0.385 \\
\hline
\end{tabular}

The Mean Scores in the Pre-test and the Post-test of the Control and the Experimental Groups. 
Table 3. The paired sample tests of the control group and the experimental group

\begin{tabular}{|c|c|c|c|c|c|c|c|c|c|}
\hline & & \multicolumn{5}{|c|}{ Paired Differences } & \multirow[b]{3}{*}{$\mathrm{t}$} & \multirow[b]{3}{*}{ df } & \multirow{3}{*}{$\begin{array}{l}\text { Sig. } \\
\text { (2-tailed) }\end{array}$} \\
\hline & & \multirow[b]{2}{*}{ Mean } & \multirow{2}{*}{$\begin{array}{l}\text { Std. } \\
\text { Deviation }\end{array}$} & \multirow{2}{*}{$\begin{array}{l}\text { Std. } \\
\text { Error } \\
\text { Mean }\end{array}$} & \multicolumn{2}{|c|}{$\begin{array}{l}95 \% \text { Confidence of } \\
\text { Interval Difference }\end{array}$} & & & \\
\hline & & & & & Lower & Upper & & & \\
\hline \multirow[t]{2}{*}{ Control Group } & Pre-test & 12.52 & 2.931 & .586 & -12.730 & -10.310 & -19.649 & 24 & .000 \\
\hline & Post-test & 13.48 & 2.756 & .551 & -13.617 & -11.343 & -22.645 & 24 & .000 \\
\hline \multirow{2}{*}{$\begin{array}{l}\text { Experimental } \\
\text { Group }\end{array}$} & Pre-test & 11.16 & 2.853 & .571 & -10.338 & -7.982 & -16.053 & 24 & .000 \\
\hline & Post-test & 15.72 & 1.926 & .385 & -14.515 & -12.925 & -35.615 & 24 & .000 \\
\hline
\end{tabular}

The paired sample tests of the control group and the experimental group

As shown in Table 2 and Table 3, the mean scores on the pre-test and the post-test for the control group are 12.52 and 13.48 respectively and the mean scores of the experimental group on the pre-test and the post-test are 11.16 and 15.72 respectively. These results show that there are statistically significant differences in the mean scores in favour of the post-test for both groups. In addition, the scores of students in the post-test for the two groups and the performances of students are evaluated in five areas: listening; vocabulary; grammar; reading; and writing. The independent sample $t$-test is used to measure the performances of students in these areas and to check whether the assumption: if there is statistically significant difference for Saudi college students between learning EFL listening, vocabulary, grammar, reading and writing using smartphones or paper materials is valid or not. The mean scores, standard deviations and the P-values are calculated and their results are shown in Table 4, Table 5, Table 6 and Figure 1.

Table 4. The group statistics of the control group and the experimental group

\begin{tabular}{llllll}
\hline & Control and Experimental Group & $\mathrm{N}$ & Mean & Std. Deviation & Std. Error Mean \\
\hline \multirow{2}{*}{ Listening } & Control Group & 25 & 2.12 & .726 & .145 \\
& Experimental Group & 25 & 2.88 & .666 & .133 \\
Vocabulary & Control Group & 25 & 2.16 & .987 & .197 \\
& Experimental Group & 25 & 3.20 & .957 & .191 \\
\multirow{2}{*}{ Grammar } & Control Group & 25 & 2.24 & .879 & .176 \\
& Experimental Group & 25 & 3.00 & .707 & .141 \\
\multirow{2}{*}{ Reading } & Control Group & 25 & 2.12 & .971 & .194 \\
& Experimental Group & 25 & 3.12 & 1.054 & .211 \\
\multirow{2}{*}{ Writing } & Control Group & 25 & 2.52 & .918 & .184 \\
& Experimental Group & 25 & 3.28 & .980 & .196 \\
\hline
\end{tabular}

The Group Statistics of the Control and the Experimental Groups. 


\section{Macrothink}

Education and Linguistics Research

ISSN 2377-1356

2015, Vol. 1, No. 2

Table 5. The Independent Samples Test of the Control Group and the Experimental Group

Levene's Test

for Equality of

Variances

$\begin{array}{llllc}\text { F Sig. } & \mathrm{t} & \mathrm{df} & \begin{array}{c}\text { Sig. } \\ \text { (2-tailed) }\end{array} & \begin{array}{c}\text { Mean } \\ \text { Difference }\end{array}\end{array}$

\begin{tabular}{llcccccc}
\hline Listening & Equal variances assumed & .005 & .944 & -3.858 & 48 & .000 & -.760 \\
\hline & Equal variances not assumed & & & -3.858 & 47.648 & .000 & -.760 \\
\hline Vocabulary & Equal variances assumed & .068 & .796 & -3.782 & 48 & .000 & -1.040 \\
\hline & Equal variances not assumed & & & -3.782 & 47.957 & .000 & -1.040 \\
\hline Grammar & Equal variances assumed & 2.519 & .119 & -3.368 & 48 & .002 & -.760 \\
\hline \multirow{2}{*}{ Reading } & Equal variances not assumed & & & -3.368 & 45.886 & .002 & -.760 \\
\hline \multirow{2}{*}{ Writing } & Equal variances assumed & .295 & .590 & -3.489 & 48 & .001 & -1.000 \\
\hline & Equal variances not assumed & & & -3.489 & 47.686 & .001 & -1.000 \\
\hline
\end{tabular}

The Independent Samples Test of the Control and the Experimental Groups.

As shown in Table 5, the independent-sample $t$-test results show the differences are not statistically significant in all areas: listening $(\mathrm{M}=2.12, \mathrm{SD}=.726, \mathrm{~N}=25)$, vocabulary $(\mathrm{M}=$ $2.16, \mathrm{SD}=.987, \mathrm{~N}=25)$, grammar $(\mathrm{M}=2.24, \mathrm{SD}=.879, \mathrm{~N}=25)$, reading $(\mathrm{M}=2.12, \mathrm{SD}=.971$, $\mathrm{N}=25)$ and the writing $(\mathrm{M}=2.52, \mathrm{SD}=.918, \mathrm{~N}=25)$. Their t-values of $-3.858,-3.782,-3.368$, -3.489 , and -2.830 respectively with F-values of $.005, .068,2.519, .295$, and .133 which are larger than 0.05 , the level of significance indicate that these groups are not significantly different. Comparing their mean scores, no variations of performances in all areas of the test are found. 
Table 6. The ANOVA test of the control group and the experimental group

\begin{tabular}{|c|c|c|c|c|c|c|}
\hline & & Sum of Squares & df & Mean Square & $\mathrm{F}$ & Sig. \\
\hline \multirow[t]{3}{*}{ Listening } & Between Groups & 7.220 & 1 & 7.220 & 14.887 & .000 \\
\hline & Within Groups & 23.280 & 48 & .485 & & \\
\hline & Total & 30.500 & 49 & & & \\
\hline \multirow[t]{3}{*}{ Vocabulary } & Between Groups & 13.520 & 1 & 13.520 & 14.307 & .000 \\
\hline & Within Groups & 45.360 & 48 & .945 & & \\
\hline & Total & 58.880 & 49 & & & \\
\hline \multirow[t]{3}{*}{ Grammar } & Between Groups & 7.220 & 1 & 7.220 & 11.340 & .002 \\
\hline & Within Groups & 30.560 & 48 & .637 & & \\
\hline & Total & 37.780 & 49 & & & \\
\hline \multirow[t]{3}{*}{ Reading } & Between Groups & 12.500 & 1 & 12.500 & 12.175 & .001 \\
\hline & Within Groups & 49.280 & 48 & 1.027 & & \\
\hline & Total & 61.780 & 49 & & & \\
\hline \multirow[t]{3}{*}{ Writing } & Between Groups & 7.220 & 1 & 7.220 & 8.007 & .007 \\
\hline & Within Groups & 43.280 & 48 & .902 & & \\
\hline & Total & 50.500 & 49 & & & \\
\hline
\end{tabular}

The ANOVA Test of the Control Group and the Experimental Group.

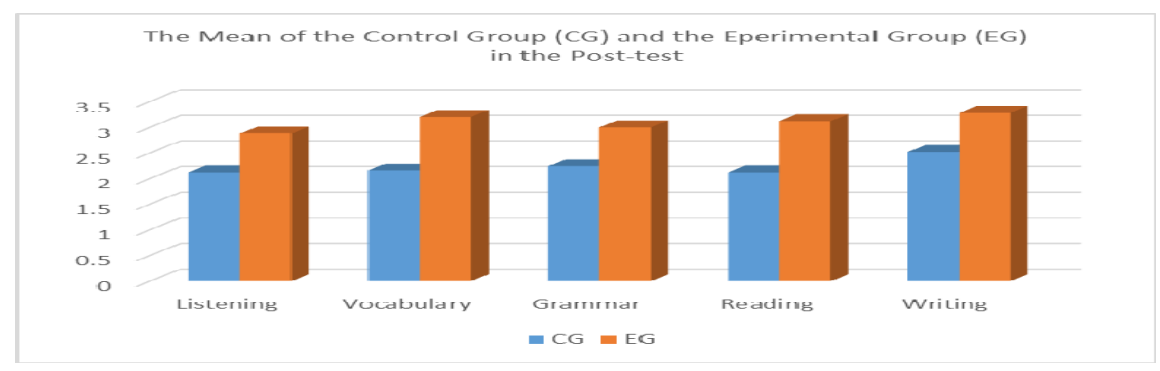

Figure 1. The mean scores of the control and the experimental groups

\subsection{Results Related to Question 2}

What are the frequent areas wherein smartphones help in learning EFL?

To measure frequent areas wherein smartphones help in learning EFL, the researcher designed a questionnaire for that purpose. The questionnaire was introduced to students in the experimental group. As shown in the methodology in section 4.4.2., it contains 30 items, divided into five categories. Category A (1-4) is about vocabulary, category B (5-12) is about pronunciation, listening and speaking, category $\mathrm{C}(13-20)$ is about reading and writing, 
category D (21-22) is about grammar and category E (23-30) is about other uses of smartphones. To measure these frequent areas, the $t$-test for independent samples is used. The mean scores and standard deviations are calculated. The frequency and the percentages of respondents in these five categories are as follows:

Table 7. The frequency and percentages of respondents of using smartphones in learning vocabulary

\begin{tabular}{|c|c|c|c|c|c|c|}
\hline & \multicolumn{2}{|l|}{ Always } & \multicolumn{2}{|l|}{ Sometimes } & \multicolumn{2}{|l|}{ Never } \\
\hline & Frequency & Percent \% & Frequency & Percent \% & Frequency & Percent \% \\
\hline \multicolumn{7}{|l|}{ Vocabulary } \\
\hline $\begin{array}{l}\text { 1. I use my smartphone as a } \\
\text { visual vocabulary notebook. }\end{array}$ & 4 & 8 & 19 & 38 & 27 & 54 \\
\hline 2. I record new vocabulary on it. & 8 & 16 & 23 & 46 & 19 & 38 \\
\hline $\begin{array}{l}\text { 3. I use online dictionaries and } \\
\text { thesauruses for words' } \\
\text { definitions. }\end{array}$ & 11 & 22 & 15 & 30 & 24 & 48 \\
\hline $\begin{array}{l}\text { 4. I use it to memorize the } \\
\text { vocabulary anytime and } \\
\text { everywhere. }\end{array}$ & 12 & 24 & 14 & 28 & 24 & 48 \\
\hline Average & & 17.5 & & 35.5 & & 47 \\
\hline
\end{tabular}

The Frequency and Percentages of Using Smartphones in Vocabulary.

Table 7 shows the frequent respondents and the percentages of using smartphones in learning vocabulary. For the first statement which is about "using smartphones as a visual vocabulary notebook", 4 respondents representing (8\%) say they always use smartphones as visual vocabulary notebooks, 19 respondents representing (38\%) argue, they sometimes do that and 27 respondents representing (54\%) say they never use smartphones as visual vocabulary notebooks. The second statement which is about "recording new vocabulary on smartphones", 8 respondents representing (16\%) say, they always record new vocabulary on their smartphones, 23 respondents representing (46\%) state, they sometimes do so and 19 respondents representing (38\%) say, they never record new vocabulary on smartphones. For the third statement "using online dictionaries and thesauruses for words' definitions", 11 respondents representing (22\%) maintain they always use online dictionaries and thesauruses for words' definitions, 15 respondents representing (30\%) say they sometimes do so, and 24 respondents representing (48\%) argue they never use online dictionaries and thesauruses for words' definitions. The fourth statement "using smartphones to memorize the vocabulary anytime and anywhere" 12 respondents representing (24\%) agree, they always use smartphones to memorize vocabulary, 14 respondents representing (28\%) claim they sometimes use smartphones in order to memorize vocabulary, and 24 respondents 
representing (48\%) state, they never use smartphones for that purpose. The average percentage of respondents who always use smartphones in learning vocabulary is $17.5 \%$, who sometimes do that is $35.5 \%$, and who never use smartphones in learning vocabulary is $47 \%$.

Table 8. The frequency and percentages of respondents of using smartphones in pronunciation, listening and speaking

\begin{tabular}{|c|c|c|c|c|c|c|}
\hline & \multicolumn{2}{|c|}{ Always } & \multicolumn{2}{|c|}{ Sometimes } & \multicolumn{2}{|c|}{ Never } \\
\hline & Frequency & Percent \% & Frequency & Percent \% & Frequency & Percent \% \\
\hline \multicolumn{7}{|l|}{ Pronunciation, Listening \& } \\
\hline Speaking & & & & & & \\
\hline $\begin{array}{l}\text { 5. I make audio, video and } \\
\text { pictorial recordings }\end{array}$ & 12 & 24 & 22 & 44 & 16 & 32 \\
\hline $\begin{array}{l}\text { 6. I record my speech and share } \\
\text { it with my colleagues for } \\
\text { feedback. }\end{array}$ & 6 & 12 & 23 & 46 & 21 & 42 \\
\hline $\begin{array}{l}\text { 7. I record students' speeches } \\
\text { and later listen to them. }\end{array}$ & 2 & 4 & 22 & 44 & 26 & 52 \\
\hline $\begin{array}{l}\text { 8. I record the interaction of } \\
\text { native speakers for listening } \\
\text { and reflection purposes. }\end{array}$ & 2 & 4 & 26 & 52 & 22 & 44 \\
\hline $\begin{array}{l}\text { 9. I archive and upload different } \\
\text { kinds of multimedia. }\end{array}$ & 6 & 12 & 22 & 44 & 22 & 44 \\
\hline $\begin{array}{l}\text { 10. I upload recordings / } \\
\text { photographs / video clips to a } \\
\text { group blog. }\end{array}$ & 6 & 12 & 21 & 42 & 23 & 46 \\
\hline $\begin{array}{l}\text { 11. I download English language } \\
\text { audio and video files and } \\
\text { listen to them. }\end{array}$ & 5 & 10 & 23 & 46 & 22 & 44 \\
\hline $\begin{array}{l}\text { 12. I practice pronunciation by } \\
\text { recording audio materials. }\end{array}$ & 4 & 8 & 24 & 48 & 22 & 44 \\
\hline Average & & 10.7 & & 45.8 & & 43.5 \\
\hline
\end{tabular}

The Frequency and Percentages of Using Smartphones in Pronunciation, Listening and Speaking.

Table 8 shows the frequent respondents and the percentages of using smartphones in pronunciation, listening and speaking. The fifth statement which is about "making audio, video and pictorial recordings", 12 respondents representing (24\%) claim they always make audio, video and pictorial recording via smartphones, 22 respondents representing (44\%) say, 
they sometimes do that and 16 respondents representing (32\%) claim they never use smartphones to make audio, video and pictorial recordings. For the sixth statement "recording their speeches and sharing them with colleagues for feedback", 6 respondents representing $(12 \%)$ argue they always record their speeches on their smartphones and share them with friends, 23 respondents representing (46\%) maintain they sometimes do so, and 21 respondents representing (42\%) state, they never record on smartphones or share them with their friends. Statement number seven which is about "recording th/e students' speeches and listen to them", 2 respondents representing (4\%) assert they always record students' speeches and listen to them, 22 representing (44\%) say they sometimes do that and 22 respondents representing (44\%) argue they never record students' speeches and later listen to them. The eighth statement "recording native to native speakers' interactions to listen to and reflect on them" 2 respondents representing (4\%) agree they always record native speakers' interactions for listening and reflection purposes, 26 respondents representing (52\%) maintain they sometimes do that and 22 respondents representing (44\%) argue they never record native speakers' interactions for listening and reflection purposes. The ninth statement "archiving and uploading different kinds of multimedia", 6 respondents representing (12\%) maintain they always archive and/or upload recordings, photographs, video clips to an individual reflective blog, 22 respondents representing (44\%) say they sometimes do so, and 22 respondents representing (44\%) claim they never do these actions. The tenth statement which is about "uploading recordings, photographs, video clips to group blogs" 6 respondents representing (12\%) maintain they always upload recordings, photographs, video clips to group blogs, 21 respondents representing (42\%) argue they sometimes do that, and 23 respondents representing (46\%) state, they never upload recordings, photographs, video clips to group blogs. The eleventh statement "downloading English language audio files and listening to them" 5 respondents representing (10\%) assert they always download English language audio files and listen to them, 23 respondents representing (46\%) say they sometimes do that, 22 respondents representing (44\%) state they never download English language audio files and listen to them. For the twelfth statement, which is about "practising pronunciation by recording audio materials" 4 respondents representing (8\%) state they practise pronunciation by recording audio materials, 24 respondents representing $(48 \%)$ declare they sometimes do that, and 22 respondents representing (44\%) profess they never practise pronunciation by recording audio materials. The average percentage of respondents who always use smartphones in in pronunciation, listening and speaking is $10.7 \%$, who sometimes do that is $45.8 \%$, and who never use smartphones in pronunciation, listening and speaking is $43.5 \%$. 
Table 9. The frequency and percentages of respondents of using smartphones in reading and writing

\begin{tabular}{|c|c|c|c|c|c|c|}
\hline & \multicolumn{2}{|c|}{ Always } & \multicolumn{2}{|c|}{ Sometimes } & \multicolumn{2}{|c|}{ Never } \\
\hline & Frequency & Percent $\%$ & Frequency & Percent $\%$ & Frequency & Percent $\%$ \\
\hline \multicolumn{7}{|l|}{ Reading \& writing } \\
\hline $\begin{array}{l}\text { 13. I download and read digital English } \\
\text { books, newspapers and magazines. }\end{array}$ & 8 & 16 & 23 & 46 & 19 & 38 \\
\hline $\begin{array}{l}\text { 14. I participate in different activities } \\
\text { related to English. }\end{array}$ & 5 & 10 & 21 & 42 & 24 & 48 \\
\hline 15. I use it to take notes in class. & 8 & 16 & 25 & 50 & 17 & 34 \\
\hline $\begin{array}{l}\text { 16. I use it to write out my thoughts in } \\
\text { English. }\end{array}$ & 3 & 6 & 26 & 52 & 21 & 42 \\
\hline $\begin{array}{l}\text { 17. I use it to write e-mails and } \\
\text { messages in English. }\end{array}$ & 9 & 18 & 19 & 38 & 22 & 44 \\
\hline $\begin{array}{l}\text { 18. I use it to chat and tweet in } \\
\text { English. }\end{array}$ & 7 & 14 & 20 & 40 & 23 & 46 \\
\hline $\begin{array}{l}\text { 19. Hashtags develop my ability to } \\
\text { summarize. }\end{array}$ & 3 & 6 & 24 & 48 & 23 & 46 \\
\hline $\begin{array}{l}\text { 20. The sound effects on it as stimulus } \\
\text { develops my writing. }\end{array}$ & 8 & 16 & 24 & 48 & 18 & 36 \\
\hline Average & & 12.8 & & 45.5 & & 41.8 \\
\hline
\end{tabular}

The Frequency and Percentages of Using Smartphones in Reading and Writing.

Table 9 shows the frequent respondents and the percentages of using smartphones in reading and writing. Statement number 13 which is about "downloading and reading digital English books, newspapers and magazines", 8 respondents representing (16\%) claim they always download and read digital English books, newspapers and magazines, 23 respondents representing (46\%) say they sometimes do that and 19 respondents representing (38\%) assert they never download and read digital English books, newspapers and magazines via smartphones. For statement number 14 "participating in different activities related to English" 5 respondents representing (10\%) affirm they always participate in English-related activities, 21 respondents representing (42\%) claim they sometimes do so, and 24 respondents representing (48\%) say they never participate in English-related activities. Statement number fifteen which is about "using smartphones to take notes in class", 8 respondents representing (16\%) state they always use smartphones to take notes in class, 25 representing (50\%) claim they sometimes do that and 17 respondents representing (34\%) argue they never use smartphones to take notes in class. For statement number sixteen "using smartphones to write thoughts in English" 3 respondents representing (6\%) agree they always use smartphones to write thoughts in English, 26 respondents representing (52\%) claim they 
sometimes do so, and 21 respondents representing (42\%) claim they never use smartphones to write thoughts in English. Statement number seventeen which is about "using smartphones to write e-mails and messages in English" 9 respondents representing (18\%) maintain they always use smartphones to write e-mails and messages in English, 19 respondents representing (38\%) say they sometimes do so, and 22 respondents representing (44\%) claim they never use smartphones to write e-mails and messages in English. About statement number eighteen which is about "using smartphones to chat and tweet in English" 7 respondents representing (14\%) maintain they always use smartphones to write e-mails and messages in English, 20 respondents representing (40\%) say they sometimes do that, and 23 respondents representing (46\%) argue they never use smartphones to write e-mails and messages in English. The nineteenth statement which asks "whether Hashtags develop students' abilities to summarize" 3 respondents representing (6\%) assert Hashtags always develop their abilities to summarize, 24 respondents representing (48\%) say they sometimes do that, 23 respondents representing (46\%) state that Hashtags never develop their abilities to summarize. For the twentieth statement which is about "the role of sound effects in developing writing" 8 respondents representing (16\%) state sound effects on smartphones always develop writing, 24 respondents representing (48\%) declare they sometimes do that, and 18 respondents representing (36\%) claim sound effects on smartphones never develop writing. The average percentage of respondents who always use smartphones in reading and writing is $12.8 \%$, who sometimes do that is $45.5 \%$, and who never use smartphones in reading and writing is $41.8 \%$.

Table 10. The frequency and percentages of respondents of using smartphones in grammar

\begin{tabular}{|c|c|c|c|c|c|c|}
\hline & \multicolumn{2}{|c|}{ Always } & \multicolumn{2}{|c|}{ Sometimes } & \multicolumn{2}{|c|}{ Never } \\
\hline & Frequency & Percent $\%$ & Frequency & Percent $\%$ & Frequency & Percent $\%$ \\
\hline \multicolumn{7}{|l|}{ Grammar } \\
\hline $\begin{array}{l}\text { 21. It improves my grammatical } \\
\text { accuracy. }\end{array}$ & 8 & 16 & 21 & 42 & 21 & 42 \\
\hline $\begin{array}{l}\text { 22. I send messages for } \\
\text { grammar practice to my } \\
\text { teachers and classmates for } \\
\text { corrections. }\end{array}$ & 4 & 8 & 25 & 50 & 21 & 42 \\
\hline Average & & $12 \%$ & & $46 \%$ & & $42 \%$ \\
\hline
\end{tabular}

The Frequency and Percentages of Using Smartphones in Grammar.

Table 10 shows the frequent respondents and the percentages of using smartphones in grammar. Statement number 21 which is about "the role of smartphones in improving grammatical accuracy", 8 respondents representing (16\%) claim, smartphones always improve their grammatical accuracy, 21 respondents representing (42\%) assert they sometimes do that and 21 respondents representing (42\%) say smartphones never improve 
their grammatical accuracy. Statement number 22 which is about "sending messages for grammar practice to teachers and classmates" 4 respondents representing (8\%) maintain, they always send messages for grammar practice to teachers and classmates, 25 respondents representing (50\%) state, they sometimes do that, and 21 respondents representing $(42 \%)$ argue, they never send messages for grammar practice to teachers and classmates for corrections. The average percentage of respondents who always use smartphones in learning grammar is $12 \%$, who sometimes do that is $46 \%$, and who never use smartphones in learning vocabulary is $42 \%$.

Table 11. The Frequency and percentages of respondents of using smartphones in other uses

\begin{tabular}{|c|c|c|c|c|c|c|}
\hline & \multicolumn{2}{|c|}{ Always } & \multicolumn{2}{|c|}{ Sometimes } & \multicolumn{2}{|c|}{ Never } \\
\hline & Frequency & Percent \% & Frequency & Percent \% & Frequency & Percent \% \\
\hline \multicolumn{7}{|l|}{ Others } \\
\hline $\begin{array}{l}\text { 23. I capture class notes by my mobile } \\
\text { camera. }\end{array}$ & 13 & 26 & 14 & 28 & 23 & 46 \\
\hline $\begin{array}{l}\text { 24. I take pictures for assignment, field } \\
\text { trips and reports. }\end{array}$ & 7 & 14 & 22 & 44 & 21 & 42 \\
\hline $\begin{array}{l}\text { 25. I receive text messages from } \\
\text { teachers with class content. }\end{array}$ & 9 & 18 & 17 & 34 & 24 & 48 \\
\hline $\begin{array}{l}\text { 26. I get feedback via messages from } \\
\text { my teachers. }\end{array}$ & 7 & 14 & 24 & 48 & 19 & 38 \\
\hline $\begin{array}{l}\text { 27. I receive homework and some } \\
\text { quizzes from my teachers via my } \\
\text { smartphone. }\end{array}$ & 5 & 10 & 23 & 46 & 22 & 44 \\
\hline 28. It helps me doing my homework. & 4 & 8 & 23 & 46 & 23 & 46 \\
\hline 29. It helps me doing research. & 5 & 10 & 24 & 48 & 21 & 42 \\
\hline $\begin{array}{l}\text { 30. Social media: Facebook, } \\
\text { twitter,etc. enhances my English. }\end{array}$ & 7 & 14 & 19 & 38 & 24 & 48 \\
\hline Average & & 14.3 & & 41.5 & & 44.2 \\
\hline
\end{tabular}

The Frequency and Percentages of Using Smartphones in Other Uses.

Table 11 shows the frequent respondents and the percentages of using smartphones in other uses for smartphones. Statement number 23 which is about "capturing class notes by students' mobile cameras", 13 respondents representing (26\%) claim they always capture class notes by their mobile cameras, 14 respondents representing (28\%) assume they sometimes do that and 23 respondents $(46 \%)$ say they never capture class notes by their mobile cameras. For statement number 24 "taking pictures for assignments, field trips and reports" 7 respondents representing (14\%) affirm they always take pictures for assignments, field trips and reports, 24 respondents representing (48\%) argue they sometimes do so, and 21 respondents 
representing (42\%) declare they never take pictures for assignments, field trips and reports by their smartphones. Statement number 25 which is about 'receiving the teachers' text messages", 9 respondents representing (18\%) state they always receive text messages from their teachers, 17 representing (34\%) maintain they sometimes do that, and 24 respondents representing (48\%) argue they never receive text messages from teachers with class content. For statement number 26 "getting feedback via messages from their teachers" 7 respondents representing (14\%) agree they always get feedback via messages from their teachers, 24 respondents representing (48\%) say they sometimes do so, and 19 respondents representing (38\%) claim they never get feedback via messages from their teachers. Statement number 27 which is about "receiving homework and quizzes from teachers" 5 respondents representing $(10 \%)$ maintain they always receive homework and quizzes via smartphones, 23 respondents representing (46\%) say they sometimes do so, and 22 respondents representing (44\%) claim they never receive homework and quizzes through their smartphones. Statement number 28 which is about "how smartphones help in doing homework" 4 respondents representing (8\%) maintain smartphones always help them in doing their homework, 23 respondents representing (46\%) claim smartphones sometimes help them do that, and 23 respondents representing (46\%) say smartphones never help them in doing their homework. For statement number 29 which is about "whether smartphones help in doing research" 5 respondents representing (10\%) assert smartphones always help them in doing research, 24 respondents (48\%) say smartphones sometimes help them do so, 21 respondents $(42 \%)$ state smartphones never help them in doing research. For the last statement in this category which is about "whether social media such as Facebook, Twitter, etc. enhances their English" 7 respondents representing (14\%) state social media always enhances their English, 19 respondents representing (38\%) declare social media sometimes does that, and 24 respondents representing (48\%) profess social media never enhances their English. The average percentage of respondents who always use smartphones in other uses is $14.3 \%$, who sometimes do that is $41.5 \%$, and who never use smartphones in learning vocabulary is $44.2 \%$.

The overall average percentage of respondents who always use smartphones in learning all EFL skills is $13.5 \%$, who sometimes do so is $42.9 \%$, and those who never use smartphones in their learning skills is $43.7 \%$.

\section{Conclusion}

Based on the results of the study and data analysis, it seems reasonable to conclude that employing smartphones in teaching and learning EFL can personalize the learning experience, and encourage students to share their own learning content. In addition, mobile technology like using smartphones can drive away boredom from classroom and spur up creativity and engagement. Therefore, smartphones are hoped to change the depressed environment of traditional classrooms into loved ones and increase the students' motivation towards learning EFL.

\section{Recommendations}

Bearing in mind the conclusions derived from the study, these points are recommended to successful EFL learning using smartphones: 
1) It is important to exploit the madness among students towards smartphones in EFL learning.

2) Students require adequate training on using smartphones for academic benefits.

3) Instructors also require adequate training on designing their lesson plans using mobile technology.

4) English language teachers have to redesign their way of teaching EFL and be aware of using mobile technology to benefit their learners.

5) Setting obvious plans and clear learning objectives to use mobile technology lead to promote teaching EFL.

6) Selection of relevant and suitable applications prevent overwhelming class with technology and missing the main goal.

\section{Acknowledgement}

This work was supported by the Deanship of Scientific Research (DSR), King Abdulaziz University, Jeddah, under grant No. (D1434-20-857). The author, therefore, gratefully acknowledges the DSR technical and financial support.

\section{References}

Alexander, B. (2006). A new way of innovation for teaching and learning. Educause Review, 41(2), 32-44.

Al-Seghayer, K. (2007). The role of organizational devices in readers' construction of mental representations of hypertext content. CALICO Journal, 24, 531-559.

Al-Shehri, S. (2011). Context in our Pockets: Mobile Phones and Social Networking as Tools of Contextualizing Language Learning. 10th world conference on mobile and contextual learning. Beijing, China, 2011.

Attewell, J., Savill - Smith, C., \& Douch, R. (2009). The impact of mobile learning: Examining what it means for teaching and learning. London: Learning and Skills Network.

Attewell, J., \& Webster, T. (2004). Engaging and supporting mobile learners. In Proceedings of MLEARNING 2004: Mobile learning anytime everywhere (pp. 15-20). London, UK: Learning and Skills Development Agency.

Baleghizadeh, S., \& Oladrostam, E. (2010). The effect of mobile assisted language learning (MALL) on grammatical accuracy of EFL students. MEXTESOL Journal, 34, 1-10.

Begum, R. (2011). Prospect for Cell Phones as Instructional Tools in the EFL Classroom: A Case Study of Jahangirnagar University, Bangladesh. English Language Teaching, 4(1), 105-115. http://dx.doi.org/10.5539/elt.v4n1p105

Chinnery, G. (2006). Emerging Technologies - Going to the MALL: Mobile Assisted Language Learning. Language Learning \& Technology, 10(1), 9-16.

Chun, D. M. (2006). CALL technologies for L2 reading. In L. Ducate, \& N. Arnold (Eds.), Calling on CALL: From theory and research to new directions in foreign language teaching (pp. 69-98). CALICO Monograph Series Volume 5. Texas State University. San Marcos, TX: 
CALICO Publications.

Constantine, P. (2007). Podcasts: another source of listening input. The Internet TESL Journal. 2007. Retrieved from http://iteslj.org/Techniques/Constantine-PodcastListening.html

Cress, U., \& Kimmerle, J. (2008). A systemic and cognitive view on collaborative knowledge building with wikis. Computer-Supported Collaborative Learning, 3, 105-122. http://dx.doi.org/10.1007/s11412-007-9035-z

Duncan-Howell, J., \& Lee, K.-T. (2007). M-learning: Finding a place for mobile technologies within tertiary educational settings. In ICT: Providing choices for learners and learning. Proceedings Ascilite Singapore 2007, 223-231.

Fowler, T., Gasen, J., Roberts, L., \& Saltzberg, S. (1996). Collaborative Learning Using Technology: Issues and Approaches, proceedings of the conference, "Broadening Our Horizons: Information, Services, Technology pages 8-8-1+.

Geddes, S. J. (2004) Mobile learning in the 21st century: benefit to learners. Retrieved from http://knowledgetree.flexiblelearning.net.au/edition06/download/geddes.pdf

Hoic-Bozic, N., Mornar, V., \& Boticki, I. (2009). A Blended Learning Approach to Course Design and Implementation. IEEE Transactions on Education, 52(1), 19-30. http://dx.doi.org/10.1109/TE.2007.914945

Hoven, D., \& Palalas, A. (2011). (Re) conceptualizing design approaches for mobile language learning. CALICO Journal, 28, 699-720. http://dx.doi.org/10.11139/cj.28.3.699-720

Kolb, L. (2008). Toys to Tools: Connecting Students' Cell phones to Education. International Society for Technology in Education. The International Society for Technology Education (ISTE).

Kondo, M., Ishikawa, Y., Smith, C., Sakamoto, K., Shimomura, H., \& Wada, N. (2012). Mobile assisted language learning in university EFL courses in Japan: Developing attitudes and skills for self - regulated learning. ReCALL, 24, 169-187. http://dx.doi.org/10.1017/S0958344012000055

Koole, M. (2009). A model for framing mobile learning. In M. Ally (Ed.), Mobile learning: Transforming the delivery of education and training (pp. 25-50). Edmonton, Alberta: Athabasca University Press.

Lan, Y. J., Sung, Y. T., \& Chang, K. E. (2007). A mobile-devices-supported peer-assisted learning system for collaborative early EFL reading. Language Learning \& Technology, 11(3), 130-151.

Lan, Y. J., Sung, Y. T., \& Chang, K. E. (2009). Let us read together: Development and evaluation of a computer assisted reciprocal early English reading system. Computers \& Education, 53(4), 1188-1198. http://dx.doi.org/10.1016/j.compedu.2009.06.002

Lehner, F., \& Nosekabel, H. (2002). The role of mobile devices in e-learning first experience with e-learning http://dx.doi.org/10.1109/wmte.2002.1039229

Lu, M. (2008). Effectiveness of vocabulary learning via mobile phone. Journal of Computer Assisted Learning, 24(6), 515-525. http://dx.doi.org/10.1111/j.1365-2729.2008.00289.x

Mahgoub D. Ahmed. (2015). An Analysis of Comprehension Performance of Sudanese EFL Students. English Language Teaching, 8(7), 133-151. http://dx.doi:10.5539/elt.v8n7p133 
Md. Yunus, M. M., Hashim, H., Embi, M. A., \& Lubis, M. A. (2010). The utilization of ICT in the teaching and learning of English: 'Tell Me More'. Procedia Social and Behavioral Sciences, 9, 685-691. http://dx.doi.org/10.1016/j.sbspro.2010.12.218

Miangah, T., \& Amin, N. (2012). Mobile Assisted Language Learning. International Journal of Distributed and Parallel Systems (IJDPS), 3. http://dx.doi.org/10.5121/ijdps.2012.3126

Morris N. O. (2011). Using Technology in the EFL Classroom in Saudi Arabia (2011). AYMAT Individual Thesis/

Mosquera, F. M. (2001). CALT: Exploiting Internet Resources and Multimedia for TEFL in Developing Countries. Computer Assisted Language Learning, 14(5), 461-468. http://dx.doi.org/10.1076/call.14.5.461.5768

O'Conner. (2005). Instant Messaging: Friend or Foe of Students' Writing? New Horizon for Learning. Retrieved May 28, 2011, from http: www.newhorizon.org/strategies/literacy,o'conner,htm

Pachler, N., Bachmair, B., \& Cook, J. (2010). Mobile Learning, Structures, Agency, Practices. London: Springer.

Park, S. Y., Nam, M.-W., \& Cha, S.-B. (2012). University students' behavioral intention to use mobile learning: evaluating the technology acceptance model. British Journal of Educational Technology, 43(4), 592-605. http://dx.doi.org/10.1111/j.1467-8535.2011.01229.x Pemberton, L., \& Fallahkhair (2005) Design issues for dual device learning: interactive television and mobile phone. In: Proceedings of MLEARN 2005. http://www.mlearn.org.za/CD/papers/Pemberton\&Fallahkhair.pdf.

Reinder H. (2010). Twenty Ideas for Using Mobile Phones in the Language Classroom. ELT Forum, 46(3), 20-25, 33.

Resta, P., \& Laferrière, T. (2007). Technology in Support of Collaborative Learning. Educ Psychol Rev, 19, 65-83. http://dx.doi.org/10.1007/s10648-007-9042-7

Sarica, G. N., \& Cavus, N. (2009). New trends in 21st Century English learning. Procedia Social and Behavioral Sciences, 1, 439-445. http://dx.doi.org/10.1016/j.sbspro.2009.01.079

Seitzinger, J. (2006). Be constructive: Blogs, podcasts, and wikis as constructivist learning tools [Electronic Version].Learning Solutions e-Magazine, p. 15

Sharples, M. (2009). Methods for evaluating mobile learning. In G. Vavoula, N. Pachler, \& A. Kukulska - Hulme (Eds.), Researching mobile learning (pp. 17-40). Bern: Peter Lang.

Tanka, J., \& Paul, M. (2012). Interactions 1 Listening and Speaking, Diamond Edition. New York: McGraw Hill.

Thorton, P., \& Houser, C. (2005). Using mobile phones in English education in Japan. Journal of Computer Assisted Learning, 21, 217-228. http://dx.doi.org/10.1111/j.1365-2729.2005.00129.x

Traxler, J. (2009b). Learning in a mobile age. International Journal of Mobile and Blended Learning, 1, 1-12. http://dx.doi.org/10.4018/jmbl.2009010101

Zhao, Y. (2005). The future of research in technology and second language education. In Y. Zhao (Ed.), Research in technology and second language learning: Developments and directions (pp.445-457). Greenwich, CT: Information Age Publishing, Inc. 


\section{Macrothink \\ Education and Linguistics Research \\ ISSN 2377-1356 \\ 2015, Vol. 1, No. 2}

\section{Websites}

http://www.britishcouncil.org/blog/teaching-tips-how-students-can-use-mobiles-to-learn-engl $\underline{\text { ish }}$

http://www.educatorstechnology.com/2013/03/teachers-guide-to-teaching-writing.html

http://www.englishforeveryone.org

http://www.havefunteching.com

http://www.vocabtest.com/vocabulary_word_test.php?grade=9\&unit=1

\section{Appendices}

Appendix 1: The Post-test for students

ENGLISH LANGUAGE TEST

Name:

University No:

Section 1: Listening

Listen to the conversation and choose the best answer:

1. What the weather forecast for tomorrow?
a) Humid, cold and 50 percent chance of rain chance of rain
c) Clear, hot and 10 percent chance of rain chance of rain.
b) Warm, dry and 90 percent
d) Cloudy, cold and 90 percent

2. When does Bruce want to go to Bear Mountains?
a) In October
b) In November
c) In December
d) In August

3. Where does Peter want to go on vacation?
a) Texas
b) California
d) Florida
d) Ohio

4. When did Jack go to Bear Mountains?
a) Last year
b) Last month
c) Yesterday
d) Last week

5. What is Jack's idea of a perfect vacation?
a) Going to mountains
b) Staying at home
c) Swimming and snorkeling
d) Having a long drive 
Section 2: Vocabulary

Which word or word phrase best complete this sentence?

6. are buildings, pieces of equipment, or services that are provided for a particular purpose.
a) Malls
b) City Centres
c) Facilities
d) Shopping Centres

7. The basic information or training that is given to people starting a new job, school, or course is called
a) a formation period
b) an orientation
c) a placement test
d) a training period

8. Students in a dormitory do not have much since they share rooms with others.
a) friends
b) freshness
c) privacy
d) work

9. There is no in Ahmed's building, so he bought a washing machine.
a) laundry
b) restaurant
c) coffee shop
d) gym

10. I share a bathroom whereas my classmate has a private one.
a) cheap
b) special
c) big
d) common

Section 3: Grammar

11. I an amazing dream last night.
a) had
b) have
c) has
d) did not had

12. She will my breakfast in the morning.
a) cooked
b) cook
c) cooks
d) cooking

13. She has a hamburger for dinner.
a) orders
b) ordered
c) ordering
d) order

14. The manager was the number of guests.
a) counted
b) counting
c) counts
d) count

15. She up early on her trip last week.
a) woke
b) wakes
c) waking
d) wake

Section 4: Reading

What is it made of?

Story By: Andrew Frinkle

Harry was a curious boy, and his dad was pretty smart. So, when Harry saw a tree next to the porch, he asked him, "What is that tree made of?" Dad grunted his answer, "Wood... branches... leaves."

"What's that rock over there made of?"

"Rocks." Dad answered quickly.

Harry wasn't done yet, "How about the car? What is it made of?"

Dad thought for a moment on this one. "Plastic, metal, and glass mostly, and maybe some 
rubber."

"How about the air?"

"It's made of air, or kinds of air."

Harry frowned, "There are kinds of air?"

Dad sighed. He'd been trying to read the paper on the porch, but he could see his son wasn't going to let him. "There are many kinds of air, but we can't see them."

"Then how do we know they are there?"

"Scientists have studied this stuff. They have found many kinds of air and mixtures of those kinds of air."

"Like what?" Harry asked.

Dad shrugged, "There are gases like oxygen, nitrogen, helium, and others. They mix to make ozone, carbon dioxide, carbon monoxide, and other things."

Harry regarded his father as if he'd started speaking another language. "What?"

Dad groaned, "Look, everything is made up of stuff, okay?" Harry nodded, so his father continued. "Think of it like mom's pantry, but we're not baking bread and cookies here, we're making stuff. There are about 100 ingredients called elements that can be used in different amounts to make everything, but most things are only made of a few of them."

"Even me?" Harry asked in surprise.

"Yes, you're mostly carbon, hydrogen, nitrogen, and oxygen, but there are lots of little bits of other elements - ingredients - in you. Each piece is so very tiny that we can't even see it." "So what are rocks made of then, for real this time?" Harry watched his father carefully. "Rocks are made of minerals, which are made of elements like silicon and other stuff." Harry nodded, finally satisfied, at least for the moment. Dad resumed reading his paper, only to be interrupted a few minutes later with another question, "And the trees then?"

Dad gave up and went inside to hide in den to read his paper.

Use the information in the story to answer the questions below:

16. While talking about what things are made of, what is the first thing Harry asks about?
a) A tree
b) A rock
c) A car
d) The air

17. Which item does Dad revisit his answer for and answer in more detail?
a) A tree
b) A rock
c) A car
d) The air

18. Harry is most surprised to find that what is also made of elements?
a) Rocks
b) Air
c) Himself
d) Cars

19. Dad compares elements, which all things are made of, to what...?
a) types of candy
b) different letters and numbers
c) baking ingredients
d) colors of paint

20. Based on the story, how would you best describe Harry?
a) Silly
b) Curious
c) Rude
d) Happy 


\section{Section 5: Writing}

Making a formal argument

Directions: Argue for or against the statement below using a formal argument. In a formal argument, you must

1) State your position.

2) Provide point(s) that support your position.

3) Support each point with specific reasons/examples.

Statement: An apple a day keeps the doctor away

\section{Copyright Disclaimer}

Copyright reserved by the author(s).

This article is an open-access article distributed under the terms and conditions of the Creative Commons Attribution license (http://creativecommons.org/licenses/by/3.0/). 